\title{
MAPOWANIE SEKTORÓW KREATYWNYCH. W POSZUKIWANIU DEFINICJI I METODY
}

ANNA WRÓBLEWSKA

\section{WPROWADZENIE}

We wrześniu 2015 roku w przeddzień 40. Festiwalu Filmowego w Gdyni prezydent Gdyni Wojciech Szczurek uroczyście otwierał Gdyńskie Centrum Filmowe - efektowną, jasną budowlę na Placu Grunwaldzkim, położoną tuż obok świeżo odremontowanego Teatru Muzycznego. Gdyńskie Centrum Filmowe powstało w zaledwie kilkanaście miesięcy. Mieści się w nim trzysalowe kino arthousowe, Gdyńska Szkoła Filmowa, Pomorska Fundacja Filmowa (organizator Festiwalu) oraz restauracja, kawiarnia i księgarnia. Rok wcześniej gospodarz miasta, wmurowując kamień węgielny, powiedział: „Dzięki Festiwalowi Filmów Fabularnych rozpoczęła się tu miłość do kina, miłość o wielu twarzach. Dzięki twórcom rodziły się nowe pomysły - warsztaty filmowe, a następnie Gdyńska Szkoła Filmowa. Ukształtowało się tu nowe środowisko filmowe. Było to możliwe dzięki ludziom, którzy do tego łańcuszka dodawali nowe pomysły"1.

Festiwal Filmów Fabularnych został przeniesiony z Gdańska do Gdyni w 1987 roku, wbrew woli i chęci środowiska filmowego, słusznie interpretującego tę decyzję jako karę za zbytnią aktywność polityczną. Na początku lat 80. gdańskie festiwale stały się miejscem nieskrępowanej debaty na tematy społeczno-polityczne. Wielkimi wydarzeniami były projekcje legendarnych

1 A. Wróblewska, Duża dziura duży pomyst. W Gdyni buduja, http://www. portalfilmowy.pl/wydarzenia,5,19191,2,1,Duza-dziura-duzy-pomysl-W-Gdyni-buduja-foto.html [data dostępu: 15.07.16]. 
dokumentów Robotnicy '80 czy Chłopi '81. Na Festiwalu Polskich Filmów Fabularnych gościł Lech Wałęsa i inni członkowie opozycji. Po reaktywacji Festiwalu w 1984 roku (w latach 1982-1983 FPFF był zawieszony) władze uznały, że środowisku filmowemu lepiej zrobi rozbrat $\mathrm{z}$ Gdańskiem.

Jednakże po 1989 roku Gdynia, zawsze traktowana jako najmniej efektowna część trójmiejskiej aglomeracji, zaczęła stopniowo zmieniać swoje oblicze. Władze samorządowe potraktowały prestiżową imprezę jako szansę na gruntowną zmianę wizerunku miasta. W ślad za doinwestowaniem Festiwalu miasto rozpoczęło realizację szeregu inwestycji kulturalnych zarówno w infrastrukturę, jak w i projekty „miękkie”, czyli prestiżowe wydarzenia kulturalne i edukacyjne (np. festiwal muzyczny Opener, Nagroda Literacka Gdynia). Wraz z powstaniem pierwszego multipleksu - Silver Screen (obecnie Multikino) - FPFF otworzył się na publiczność. Kolejne kina i instytucje kultury stopniowo poszerzały przestrzeń festiwalową ${ }^{2}$. W 2000 roku na Festiwalu wydawano około 800 akredytacji; w 2014 roku było ich już 2600. Organizatorzy szacują, że przy okazji Festiwalu rokrocznie przyjeżdża do Gdyni 2500-3000 widzów, a do Trójmiasta i okolic przybywa do 4000 osób. W 2014 roku liczba widzów obecnych na wszystkich wydarzeniach Festiwalu wyniosła 47 tysięcy, a więc około osiem razy więcej niż piętnaście lat temu ${ }^{3} \mathrm{~W} 2016$ roku po raz pierwszy frekwencja sięgnęła 60 tysięcy widzów. Otwarte w 2015 roku Gdyńskie Centrum Filmowe, dysponujące trzema salami kinowymi, nie rozładowało tłoku - na większość projekcji konkursowych zabrakło biletów. Zatem im więcej przybywa sal kinowych i obiektów festiwalowych, tym większe zainteresowanie Festiwalem.

W 2005 roku powstała Pomorska Fundacja Filmowa, instytucja pozarządowa, założona przez miasto, samorząd Województwa Pomorskiego oraz Stowarzyszenie Filmowców Polskich, które jest pierwszym organizatorem Festiwalu. Głównym zadaniem PFF była realizacja Festiwalu Polskich Filmów Fabularnych, jednakże szybko okazało się, że nie wyczerpuje to jej potencjału. Jej prezes, a zarazem dyrektor Festiwalu, Leszek Kopeć,

2 Historia Festiwalu Polskich Filmów Fabularnych została szczegółowo opisana w monografii Film $z$ widokiem na morze. 40 lat Festiwalu Filmowego Gdańsk Gdynia, red. A. Wróblewska, Warszawa 2015, dostępnej także w wersji elektronicznej: http://www.sfp.pl/filmzwidokiemnamorze [data dostępu: 15.07.16].

3 Film $z$ widokiem na morze...., op. cit., s. 291. 
otworzył więc Pomorskie Warsztaty Filmowe - płatny kurs reżyserii filmowej, ściągający przede wszystkim twórców z Pomorza, zwłaszcza z Gdyni. Konsekwencją tego udanego (i do dziś funkcjonującego) kursu była śmiała inicjatywa podjęta przez władze miasta, zarząd Fundacji i twórców filmowych, czyli Gdyńska Szkoła Filmowa.

Założona w 2010 roku GSF to dwuletnia szkoła policealna z praktycznym programem kształcenia reżyserii filmowej, przygotowanym przez profesora Roberta Glińskiego ${ }^{4}$. Co ciekawe, kształcenie w Szkole jest bezpłatne, trzeba jednak przejść ostrą selekcję. Podobnie jak na warsztaty, do GSF zgłaszają się przede wszystkim mieszkańcy Polski północnej, zwłaszcza z Trójmiasta. Jednocześnie miasto miało spory wkład przy powstaniu serii filmów dokumentalnych i fabularnych poświęconych historii i teraźniejszości Gdyni. W 2009 roku władze samorządowe powołały Gdyński Fundusz Filmowy (jeden z tak zwanych regionalnych funduszy filmowych), zlokalizowany przy miejskiej instytucji kultury - Gdyńskim Centrum Kultury. Fundusz wspiera finansowo przede wszystkim filmy tematycznie, lokacyjnie lub produkcyjnie związane z miastem. Prezydent Gdyni mówił w jednym z wywiadów, iż:

Przestrzenie kultury budują wartość miasta. Ale wśród różnych dziedzin kultury, film czyni to najpełniej. Festiwal filmowy, Pomorska Fundacja Filmowa, Pomorskie Warsztaty Filmowe, a potem Gdyńska Szkoła Filmowa, to elementy, które tworzą filmową mapę miasta. Jednocześnie wszystkie one przyczyniły się do rozwoju produkcji filmowej w mieście. Film w Gdyni rozwija się najpełniej, najszerzej, a ma to swoje korzenie w Festiwalu. W Gdyni dynamicznie rozwija się środowisko filmowe, dlatego tworzenie dla niego miejsca jest koniecznością. W centrum Gdyni powstał cały ciąg instytucji kulturalnych: Centrum Filmowe, Teatr Muzyczny, Muzeum Marynarki Wojennej, Muzeum Miasta Gdyni. W dzisiejszym świecie ważnym elementem jest przestrzeń publiczna, która tworzy się wokół tych instytucji. Chciałbym, aby były organizowane tam wydarzenia, które najpełniej będą wykorzystywać tę przestrzeń ${ }^{5}$.

Obecnie stałym punktem w programie Festiwalu jest sekcja „Filmy z Gdyni”. Została ona powołana, aby prezentować filmy realizowane

4 Informacje o Szkole znajdują się na stronie internetowe www.gsf.pl [data dostępu: 15.07.16], sekcja: „O szkole”.

5 Film $z$ widokiem na morze..., op. cit., s. 288. 
w Gdyni i opowiadające o Gdyni. Część produkcji powstaje w firmach lub organizacjach pozarządowych założonych w mieście lub przez osoby związane z miastem (studia: Biały Smok Production, Maj Film Produkcja Filmowa, grupa artystyczna MWM Art Film).

Trzeba jednakże zauważyć, że wspieranie kinematografii jest jedynie częścią strategii kulturalnej miasta, realizowanej konsekwentnie od lat 90. Gdynia jako pierwsze miasto w Polsce przebyła drogę przekształcenia miasta postindustrialnego $\mathrm{w}$ tak zwane miasto kreatywne ${ }^{6}$. Powstanie szkolnictwa filmowego, rozwój Festiwalu czy założenie firm producenckich można bezpośrednio wiązać z polityką miejską, jednakże w przypadku inwestycji kinowych trudno o tak bezpośredni związek, choć na rozwój kultury filmowej i popularności kina w Gdyni niewątpliwie ma wpływ najważniejszy polski festiwal filmowy i tworząca się wokół niego atmosfera pozytywnego snobizmu. Organizowana od 2004 roku w rozbudowanej formie sekcja „Gdynia Dzieciom” ściąga rokrocznie od ośmiu do dziesięciu tysięcy młodych widzów?

Prezydent Gdyni, mówiąc o powstawaniu kolejnych inwestycji filmowych, użył określenia „łańcuszek”. Władze miasta widzą więc kolejne inwestycje i przedsięwzięcia filmowe jako ciąg przyczynowo-skutkowy, rozgrywający się w szerokiej czasowo perspektywie. Powstająca przez ostatnie kilkanaście lat mikrobranża filmowa w Gdyni to nic innego jak skoncentrowana na małym terenie sieć wzajemnych powiązań między podmiotami ją tworzącymi. Do stworzenia dynamicznego, pełnego opisu tej branży można zastosować atrakcyjne narzędzie badawcze: mapowanie (mapping) przemysłów kreatywnych. Ideę mapowania i metody stosowane w jej ramach chcę przedstawić poniżej.

Koncepcja mapowania po raz pierwszy została opracowana na polskim gruncie przez British Council w 2010 roku w formie raportu Mapowanie sektorów kreatywnych: narzędzia, wydanym w serii „Kreatywna Gospodarka

${ }^{6}$ Proces przekształcania miast postindustrialnych w kreatywne został w Polsce po raz pierwszy opisany przez Monikę Smoleń w książce Przemysły kultury. Wpływ na rozwój miast (Kraków 2003). Autorka przedstawia przykłady takiej drogi w przypadku miast brytyjskich, m.in. Glasgow czy Birmingham, a także Rotterdamu.

7 Dane Pomorskiej Fundacji Filmowej. 
i Przemysły Kultury"8. Za konsultację merytoryczną raportu odpowiadał dr Rafał Kasprzak ze Szkoły Głównej Handlowej w Warszawie, jeden z czołowych badaczy sektorów kreatywnych w Polsce?. We wstępie do opracowania czytamy, iż:

Potrzebujemy strategii rozwoju, aby uwolnić kreatywny potencjał każdego $\mathrm{z}$ nas $\mathrm{w}$ reakcji na dokonujące się na naszych oczach daleko idące zmiany kulturowe, ekonomiczne, społeczne i technologiczne. W tym kontekście na świecie wzrasta znaczenie koncepcji „gospodarki kreatywnej i przemysłów kultury" - staje się ona platformą łączącą kulturę, ekonomię i technologię. Nasz świat jest coraz bardziej zdominowany przez obrazy, dźwięki, symbole, idee, które tworzą nowe miejsca pracy, bogactwo i nową kulturę. Wielka Brytania jest liderem w propagowaniu tej koncepcji, stymulując nie tylko gospodarkę, ale także promując włączenie społeczne oraz różnorodność kulturową ${ }^{10}$.

Nauka o przemysłach kreatywnych jest przynależna ekonomice kultury, która, jako subdyscyplina naukowa, wyrosła i rozwinęła się na gruncie anglosaskim (w Wielkiej Brytanii, Stanach Zjednoczonych, Australii). Stąd zapewne sformułowana na wstępie edukacyjna misja British Council.

Zanim jednak zajmiemy się samą ideą mapowania, warto przyjrzeć się kluczowym pojęciom, wokół których budowany jest ten wywód.

\section{PRZEMYSŁY KULTURY}

Pojęcie sektorów kreatywnych, przemysłów kreatywnych czy też przemysłów kultury jest już na polskim gruncie dobrze znane. Pierwsze polskie publikacje na temat przemysłów kultury i ekonomiki kultury, obejmujące także kwestie definicyjne, ukazały się na początku XXI wieku. Przełomowa praca doktorska Moniki Smoleń z Uniwersytetu Jagiellońskiego - Przemysły kultury. Wpływ na rozwój miast - zawierała nie tylko podsumowanie ewolucji kluczowych pojęć, ale także pierwsze opracowanie podstaw teorii

8 BOP Consulting, Mapowanie sektorów kreatywnych: narzędzia, tłum. J. Puchalska, Warszawa 2010.

9 R. Kasprzak, Przemysty kreatywne w Polsce. Uwarunkowania i perspektywy, Warszawa 2013.

${ }^{10}$ Mapowanie sektorów kreatywnych..., op. cit., s. 9. 
miast kreatywnych ${ }^{11}$. W tym samym czasie na UJ ukazały się także inne prace poświęcone ekonomii kultury oraz pierwsze publikacje Instytutu Badań nad Gospodarką w Gdańsku, który do dzisiaj poświęca przemysłom kreatywnym wiele uwagi ${ }^{12}$. Definicje przemysłów kultury i przemysłów kreatywnych były w kolejnych latach przytaczane i omawiane w książkach wydawanych przez Narodowe Centrum Kultury w serii „Kultura się liczy!”, stanowiącej dzisiaj podstawę biblioteki każdego badacza związków kultury i ekonomii ${ }^{13}$. Może on ponadto korzystać z licznych cennych raportów eksperckich, zamawianych w ostatnich latach przez Narodowe Centrum Kultury, MKIDN, a także samorządy, oraz z prac innych polskich badaczy (m.in. Doroty Ilczuk, Rafała Kasprzaka, Tadeusza Stryjakiewicza, Jacka Purchli, Jerzego Hausnera, Krzysztofa Stachowiaka, Andrzeja Klasika). Nie ma więc sensu po raz kolejny przytaczać kilkunastu istniejących definicji przemysłów kreatywnych i ich klasyfikacji. Można zamiast tego posłużyć się prostą, acz efektowną teorią jednego z najwybitniejszych ekonomistów kultury, profesora Uniwersytetu w Sydney, Davida Throsby'ego:

[...] w praktyce słowo 'przemysł' w odniesieniu do sztuki i kultury koncentruje uwagę na ekonomicznych procesach produkcji, wprowadzania na rynek, dystrybucji i sprzedaży towarów i usług kulturalnych. Termin 'przemysł kultury' we współczesnym użyciu rzeczywiście przywołuje na myśl ekonomiczny potencjał produkcji kulturowej w postaci wytwarzania towarów, generowania miejsc pracy i dochodów oraz zaspokajania popytu konsumentów, niezależnie od innych, szlachetniejszych celów, jakim służy działalność artystów i dobry smak koneserów. Wielu przedstawicieli sektora kultury, a wśród nich prawdopodobnie również ci artyści, których funkcje celu obejmują jakiś element zysku finansowego, z zadowoleniem przyjmuje

${ }_{11}$ Por. M. Smoleń, op. cit.

12 Por. Kultura i przemysty kultury szansą rozwojowa dla Polski, red. J. Szomburg, Gdańsk 2002.

13 Por. R. Towse, Ekonomia kultury. Kompendium, tłum. Ł. Skrok, H. Dębowski, K.L. Pogorzelski, Warszawa 2011; R. Florida, Narodziny klasy kreatywnej oraz jej wpływ na przeobrażenia $w$ charakterze pracy, wypoczynku, społeczeństwa i życia codziennego, tłum. M. Penkala, T. Krzyżanowski, Warszawa 2010; D. Throsby, Ekonomia i kultura, tłum. O. Siara, Warszawa 2010; Od przemysłów kultury do kreatywnej gospodarki, red. A. Gwóźdź, Warszawa 2010. 
jednak tezę, że działalność kulturalna ma znaczący wkład w gospodarkę. Ich motywacja jest następująca: skoro kultura ogólnie, a sztuka w szczególności, mają zyskać na znaczeniu, zwłaszcza w kategoriach politycznych, w świecie, w którym królują ekonomiści, to muszą dowieść swojego znaczenia dla gospodarki; a nie ma na to lepszego sposobu, niż kultywowanie wizerunku sztuki jako przemysłu, większego (przynajmniej w Australii) niż rynek piwa i obuwia sportowego ${ }^{14}$.

W swojej najsłynniejszej książce Ekonomia i kultura David Throsby klasyfikuje przemysły kreatywne według teorii okręgów koncentrycznych. Okrąg skupiony wokół źródła twórczych idei rozszerza się, w miarę, jak idee te łączą się z kolejnymi nakładami na produkcję. W centrum okręgu, w najmniejszym, środkowo umiejscowionym kręgu, znajdują się tradycyjne sztuki kreatywne: muzyka, taniec, teatr, literatura, sztuki wizualne, rękodzieło, nowoczesne sztuki audiowizualne. Krąg drugi - nazwijmy go środkowym, to te przemysły, których produkcja obejmuje także te rodzaje usług i produktów niepowiązanych ściśle z kulturą. Czyli to, co powstaje w ramach tego przemysłu, to produkty kultury oraz inne. Do kręgu środkowego należeć będą: publikacja książek i czasopism, telewizja, radio, gazety i film. Zewnętrzny krąg tworzą przemysły, które zasadniczo funkcjonują poza strefą kultury, ale część ich produktów niesie pewne treści kulturowe. Tutaj znajdzie się reklama, która wymaga wkładu twórczego, turystyka, gdyż niektóre jej segmenty są zbudowane na podstawie kulturowej a także usługi architektoniczne, gdy architektura ma zawierać w sobie pewną symbolikę czy przekaz ${ }^{15}$. Warto dodać, że w wydanej kilka lat później książce Economics of Cultural Policy Throsby pod wpływem doświadczeń i konsultacji przeformułował model przemysłów kultury na nowy, czterookręgowy ${ }^{16}$.

W polskim piśmiennictwie kluczowe pojęcie 'creative industry' jest dwojako tłumaczone. Autorzy używają wymiennie określeń 'przemysły kultury' i 'przemysły kreatywne', intuicyjnie przypisując pierwsze z nich raczej do wewnętrznych kręgów Throsby'ego. W Wielkiej Brytanii pod pojęciem 'creative industries' rozumiemy „te przemysły, które mają źródło w indywidualnej kreatywności, umiejętnościach oraz talencie, i które wykazują potencjał do
14 D. Throsby, op. cit., s. 103
15 Ibidem, s. 103-105
16 D. Throsby, The Economics of Cultural Policy, New York 2010, s. 92. 
tworzenia dobrobytu i miejsc pracy poprzez generowanie i wykorzystywanie własności intelektualnej"17. Są to: reklama, handel antykami, architektura, rękodzieło, design, moda, film, gry komputerowe i wideo (programy służące rozrywce), muzyka, sztuki performatywne, działalność wydawnicza, oprogramowanie komputerowe, TV i radio.

\section{IDEA MAPOWANIA}

Znacznie trudniejsze okazuje się wyjaśnienie pojęcia 'mapowanie' (mapping). "Jedną z metod pozwalających krajom, regionom i miastom szacować wartość sektorów kreatywnych jest "mapowanie «" - piszą autorzy raportu Mapowanie przemysłów kreatywnych. „Mapowanie, zapoczątkowane w Wielkiej Brytanii w późnych latach 90., zdecydowanie wykracza poza kreślenie faktycznych map. Jest to skrótowe określenie zbioru metod analitycznych zbierania i przedstawiania informacji na temat skali i zakresu działalności sektorów kreatywnych. Mapowanie ma na celu pokazanie ogólnego zarysu ekonomicznej wartości sektorów, szczególnie w miejscach, gdzie wiedza o nich jest ograniczona"18. Autorzy raportu zwracają uwagę na fakt, iż bardzo często umiejscowienie, rozmiar oraz potrzeby sektorów kreatywnych nie są dobrze znane, a mapowanie to pierwszy krok, aby to zmienić. Procesu mapowania nie można jednak rozważać w próżni, gdyż powiązany jest on z innymi kwestiami - politycznymi, ekonomicznymi i praktycznymi ${ }^{19}$.

W mapowanie przemysłów kreatywnych powinny być zaangażowane osoby o różnych kwalifikacjach: od specjalistów danych branż, poprzez analityków, ekonomistów, kulturoznawców, po geografów ekonomicznych. Wykorzystuje się metody zarówno ilościowe, jak i jakościowe. Sześć głównych metod to: przegląd literatury, analiza oficjalnych danych rządowych, badania dotyczące konkretnych sektorów, analiza danych ze źródeł pozarządowych, analiza informatorów branżowych i studia przypadków. Określenie wartości sektorów kreatywnych w globalnej gospodarce możliwe

${ }_{17}$ Cyt. za: T. Kukołowicz, Dwa pomysty na przemysty kreatywne, referat wygłoszony podczas Regionalnego Kongresu Kultury w Łodzi, 27-29 X 2011 r.; www.kongres-kultury.pl [data dostępu: 15.07.16].

${ }_{18}$ Mapowanie przemysłów kreatywnych..., op. cit., s. 11.

19 Ibidem, s. 25. 
jest poprzez analizę wszelkich dostępnych danych dotyczących: zatrudnienia, liczby i rozmiaru firm kreatywnych, wielkości eksportu, wartości dodanej brutto czy składu siły roboczej ${ }^{20}$. Brytyjskie instytucje publiczne, rozpowszechniając ideę mapowania, skupiają się przede wszystkim na celach. Celem podstawowym mapowania jest bowiem podniesienie znaczenia sektorów kreatywnych. Mapowanie podnosi (nikłą obecnie w Europie) świadomość społeczną na temat znaczenia ekonomicznej strony kultury. Pozwala sformułować wspólne ramy odniesienia, przydatne w dyskusji na temat sektorów kreatywnych, a to z kolei wprowadza temat przemysłów kreatywnych do dyskursu gospodarczego i politycznego. Według autorów opisywanego raportu, mapowanie może być też cennym narzędziem w lobbingu klasy kreatywnej. Wszystkie te szczytne cele przykrywa jeden zasadniczy - pogłębienie wiedzy na temat tej sfery gospodarki, wciąż niedostatecznie zanalizowanej.

Sektory kreatywne stanowią zróżnicowaną i szybko zmieniającą się grupę. Czasem, przy sprzyjających uwarunkowaniach przestrzennych, sektory te łączą się w klastry, a każdy z nich zmaga się ze swoimi problemami. W idei mapowania podkreślona jest także wartość takiej analizy dla planowania: sektory kreatywne stoją przed wieloma wyzwaniami, jak np. znalezienie przestrzeni do pracy w przystępnej cenie, uzyskanie dostępu do szybkiego, szerokopasmowego Internetu i znalezienie odpowiednio wykwalifikowanych pracowników. Mapowanie pozwala określić potrzeby przemysłów kreatywnych i opracować rozwiązania umożliwiające ich zaspokojenie ${ }^{21}$.

Można więc podsumować powyższe rozważania stwierdzeniem, że mapowanie sektorów kreatywnych polega na możliwie najbardziej pogłębionym, opartym o dostępne dane, opisie branż kulturalnych i „okołokulturalnych” na danym terenie.

\section{PROBLEMY DEFINICYJNE}

Samo użycie terminu 'mapowanie' budzi jednak pewne zastrzeżenia co do jego ścisłości. Krzysztof Stachowiak, geograf ekonomiczny z Uniwersytetu im. Adama Mickiewicza w Poznaniu badający skupiska sektorów kreatywnych,

20 Ibidem, s. 40-48.

${ }^{21}$ Ibidem, s. 26-28. 
klastry kreatywne, a także porządkujący wiedzę teoretyczną i dorobek naukowy w tym obszarze, stwierdza, iż:

$\mathrm{Z}$ geograficznego punktu widzenia sam termin 'mapowanie' jest trochę nieszczęśliwym tłumaczeniem angielskiego 'mapping', równie trochę nieszczęśliwie użytego w oryginale. W opracowaniu British Council ten termin pojawił się właśnie w tej postaci, a wcześniej używał go również brytyjski DCMS [Department for Culture, Media \& Sport - przyp. A.W.], np. w opracowaniu Creative Industries Mapping Document. Mapping to w zasadzie część działań kartograficznych polegających na prostym nanoszeniu obiektów na mapę. W polskiej nomenklaturze, używanej od stuleci, to kartowanie. A owo 'mapowanie', które pojawia się w pracach British Council i DCMS, to właściwie diagnoza stanu sektora kreatywnego. Główną metodą sporządzania takiej diagnozy jest opis statystyczny, który służy liczbowemu rozpoznaniu rozkładu badanej cechy w całej zbiorowości. Do takiego opisu używano różnych wskaźników, np. liczby podmiotów sektora kreatywnego, liczby zatrudnionych, wartości dodanej itd. Obok opisu statystycznego są też np. metody szacowania wartości, które są popularne w ekonomice kultury ${ }^{22}$.

Stachowiak przeanalizował wnikliwie metody opisu sektora kreatywnego. W artykule Problemy metodologiczne badania sektora kreatywnego zwraca uwagę, iż „badania nad różnymi aspektami sektora kreatywnego są prowadzone przy użyciu różnorodnego warsztatu metodologicznego, czasem dość wyrafinowanego. Dostarcza on sporej, ale jednak rozczłonkowanej wiedzy. Stosunkowo niewiele jest natomiast syntezy tego, co już wiemy o sektorze kreatywnym. Jest to zapewne rezultat pluralizmu metodologicznego, polegającego na stosowaniu w badaniach zarówno metod jakościowych, jak i ilościowych"23. Po przeanalizowaniu tekstów naukowych z zakresu ekonomiki kultury, Stachowiak zauważa, że w badaniach sektora kreatywnego przeważa podejście multidyscyplinarne, na które składają się przede wszystkim badania ekonomiczne, socjologiczne, geograficzne, kulturoznawcze, a także pochodzące z wielu innych dyscyplin naukowych.

22 Wywiad własny z Krzysztofem Stachowiakiem, e-mail z dnia 25.04.2016 roku. Por. także: K. Stachowiak, P. Tomczak, Przestrzenny wymiar sektora kreatywnego, Poznań 2015.

${ }^{23}$ K. Stachowiak, Problemy metodologiczne badania sektora kreatywnego, „Rozwój Regionalny i Polityka Regionalna” 2015, nr 30, s. 32. 
Wiedza naukowa o sektorze kreatywnym jest głównie wiedzą opisowo-informacyjną, a w aspekcie praktycznym - w przeważającym stopniu jawną, co wynika $\mathrm{z}$ faktu, że większość badań, opracowań czy raportów zlecanych jest przez instytucje publiczne, dążące do usystematyzowania wiedzy o świecie, w jakim działają ${ }^{24}$. Badacze sektora kreatywnego korzystają przede wszystkim z danych statystycznych pochodzących z urzędów i instytucji, organizacji pozarządowych, badań własnych, literatury oraz w dużym stopniu $\mathrm{z}$ archiwów i stron internetowych. W badaniach sektorów kreatywnych najczęściej wykorzystuje się takie czynniki, jak: wskaźniki zatrudnienia, liczba instytucji zaszeregowanych według wewnętrznych podziałów (np. instytucje kultury, organizacje non profit), wartość ekonomiczna (np. import, eksport), lokalizacja oraz inne wskaźniki charakterystyczne dla danej branży (np. tak zwany box-office w przemyśle filmowym) ${ }^{25}$.

Mapowanie w ujęciu British Council (a więc i całego brytyjskiego „resortu” kultury) będzie więc ograniczonym przestrzennie badaniem funkcjonowania sektorów kreatywnych, silnie zorientowane regionalnie. Wielokrotnie przywoływany (także w wyżej wymienianych opracowaniach) artykuł Creative Industries Mapping: Where have we come from and where are we going? podkreśla liczne trudności, na jakie natykają analitycy dążący do wyliczenia wartości sektora (wartości usług, wpływu technologii cyfrowych itd.) ${ }^{26}$.

Nie sposób nie zgodzić się z wyrażoną przez Stachowiaka uwagą dotyczącą trafności pojęcia 'mapowanie'. Choć zatem należy traktować je dość umownie, to mapping może być efektywną metodą badawczą (oraz dydaktyczną w nauce zarządzania kulturą), pozwalającą dostrzec niewidoczne gołym okiem związki kultury i ekonomii i zrozumieć rynkową siłę kultury. Należy też zwrócić uwagę na różnorodność metod, którymi można posługiwać się, diagnozując sektory kreatywne. Badania sektorów kreatywnych, z natury interdyscyplinarne, pozwalają na pewną swobodę wyboru metodologii w zależności od tego, czy prowadzone są przez kulturoznawców, czy przez ekonomistów. Jednakże stosowanie twardych danych statystycznych

${ }^{24}$ Ibidem, s. 29-30.

25 Ibidem, s. 25-28.

26 P. Higgs, S. Cunningham, Creative Industries Mapping: Where have we come from and where are we going?, „Creative Industry Journal” 2008, vol. 1, nr 1. 
bez przytoczenia szerszego tła kulturowego, bez zrozumienia warunków, w jakich na danym terenie rozwija się działalność kulturowa, może dać obraz niepełny. Najlepszym przykładem jest właśnie wspomniana na początku Gdynia: mikroskala przemysłu filmowego w tym mieście może zniechęcić badacza kierującego się takimi kryteriami, jak na przykład liczebność firm, liczba wyprodukowanych filmów rocznie, wyniki box office’a. Ale z drugiej strony stworzenie mapy firm $\mathrm{z}$ sektora kreatywnego i branż powiązanych (jak media, teatr, sztuki performatywne) wykaże ścisłe związki, jakie wytworzyły między sobą poszczególne segmenty mikrobranży. Uwidoczni się też dominująca rola instytucji państwowych na mapie, co oczywiście wynika $\mathrm{z}$ silnej ingerencji władz miasta w rozwój tej branży (a w zasadzie wręcz z dominującej, sprawczej roli samorządu terytorialnego).

Przy opracowywaniu katalogu najbardziej optymalnych metod mapowania należy moim zdaniem zwrócić szczególną uwagę na narzędzia za zakresu zarządzania strategicznego i analizy strategicznej. Nie bez powodu ekonomika kultury sięga do analizy strategicznej po narzędzia opisu polityki kulturalnej, zarządzania projektami kulturalnym czy procesów marketingowych (np. powszechnie stosowana, również w praktyce dydaktycznej, analiza SWOT). Pewna „miękkość” zarządzania strategicznego, jego wieloaspektowość, sięganie w diagnozie rzeczywistości do czynników kulturowych, społecznych czy globalnych wydaje się uprzywilejowywać metodę analizy strategicznej w ekonomice kultury, w tym także w mapowaniu.

Szczególnie przydatne wydaje się użycie do tego celu prostego i atrakcyjnego narzędzia, jakim jest wytyczenie ścieżki ekonomicznej. Ścieżka ekonomiczna jest zbiorem komplementarnych operacji odzwierciedlających całkowity proces powstawania produktu lub usługi, składający się $\mathrm{z}$ oddzielnych etapów, wykonywanych często przez przedsiębiorstwa pochodzące z różnych sektorów ${ }^{27}$. Jak zwracają uwagę Grażyna Gierszewska i Maria Romanowska, autorki wielokrotnie wznawianej publikacji Analiza strategiczna przedsiębiorstw, jeśli na ścieżce ekonomicznej odnajdziemy badane przez nas przedsiębiorstwo, może okazać się, że działa ono jednocześnie w kilku ogniwach tej ścieżki. Analizę strategiczną zazwyczaj stosuje się, by zdefiniować ruch pieniądza i wartość poszczególnych sektorów, ale

27 G. Gierszewska, M. Romanowska, Analiza strategiczna przedsiębiorstwa, Warszawa 2009, s. 134. 
jest też idealna do rozpoznania składników danego sektora. Na przykład ścieżka ekonomiczna produkcji filmu fabularnego zawierać będzie takie segmenty, jak: instytucje finansujące (publiczne, prywatne, pozarządowe itd.), przedsiębiorstwa branżowe i powiązane, firmy zajmujące się usługami, produkcją i dystrybucją, kina, organizacje upowszechniania kultury, banki $\mathrm{i}$ inne instytucje finansujące (dobrowolnie lub obligatoryjnie), wydawnictwa i szereg innych podmiotów.

Podobnie przydatna może okazać się analiza tak zwanego łańcucha wartości. Każdy sektor jest ogniwem w łańcuchu wartości gospodarki, natomiast każde przedsiębiorstwo stanowi ogniwo łańcucha składającego się $\mathrm{z}$ - by odnieść się do terminologii z zakresu zarządzania strategicznego - dostawców przedsiębiorstwa, przedsiębiorstwa i jego odbiorców. W uproszczeniu można więc określić łańcuch wartości jako drogę od dostawców, poprzez przedsiębiorstwo i dystrybutorów, aż do nabywcó $\mathrm{w}^{28}$. W przypadku rynku wydawniczego będzie to łańcuch od autorów, poprzez wydawnictwa i firmy z nimi współpracujące, hurtownie, sklepy i inne punkty detaliczne, aż do klientów.

Te dwie proste metody analizy strategicznej mogą okazać się przydatne w zrozumieniu zasad ekonomicznych rządzących przemysłami kultury, łatwo dają się też zastosować w procesie kreślenia map sektorów kreatywnych.

\section{PODSUMOWANIE}

Gdyby więc chcieć stworzyć mapę przemysłu filmowego na terenie Gdyni, należałoby umieścić na niej następujące podmioty:

- instytucje o charakterze centralnym, publiczne: Urząd Miasta, Samorząd Województwa Pomorskiego, Agencja Rozwoju Gdyni (administrator Gdyńskiego Centrum Filmowego);

- kina (Helios, Multikino, GCF);

- organizatorzy przedsięwzięć z zakresu upowszechniania kultury filmowej i edukacji filmowej (na czele z Pomorską Fundacją Filmową i Gdyńskim Centrum Kultury);

- producenci filmowi ulokowani w Gdyni oraz firmy świadczące usługi filmowe.

28 Ibidem, s. 135. 
Ponadto na mapę należałoby nanieść podmioty działające w sektorach powiązanych, czyli:

- media lokalne, aktywnie informujące o kulturze filmowej;

- teatry miejskie, które współpracują ze środowiskiem filmowców w zakresie wynajmu sal, rekwizytów, scenografii, kostiumów, a także tworzą wspólnie pewne punkty programu wydarzeń filmowych;

- miejscowe drukarnie, punkty poligraficzne, firmy zajmujące się usługami w zakresie „twardego” marketingu;

- szkoły podstawowe, gimnazjalne i ponadgimnazjalne, z którymi współpracują organizatorzy wydarzeń kulturalnych;

- firmy wynajmujące sprzęt (scenę, światło, telebimy, sanitariaty) na wydarzenia filmowe, zwłaszcza na festiwal i do realizacji filmów.

Następnie należałoby oszacować realną wielkość każdej grupy, liczbę podmiotów aktywnie działających na danym obszarze i spróbować ustalić pewne dane liczbowe: wyniki lokalnego box office'u (niestety wielkie sieci kinowe nie podają tego typu danych od 2010 roku; box office jest liczony na podstawie danych dystrybutorów), liczbę filmów wyprodukowanych w mieście, liczbę wydarzeń kulturalnych związanych z Gdynią, liczbę przedsięwzięć edukacyjnych itd. Jednocześnie należy się zastanowić, czy mapowaniem nie należałoby objąć, ze względu na specyfikę terytorialną, całego Trójmiasta. W Gdańsku bowiem tworzy się stopniowo lokalne środowisko filmowe, które, choć nieliczne, wydaje się mocno rozwijać i działać aktywnie w poszukiwaniu projektów i środków na ich realizację.

Podsumowując niniejsze rozważania, należy przyjąć za zasadne zastrzeżenie Krzysztofa Stachowiaka dotyczące mylącego terminu 'mapowanie'. Ten rodzaj analizy polega przede wszystkim na możliwie całościowym spojrzeniu na przemysł kultury i wykazaniu jego związków z innymi sektorami. Jest to także, co istotne, bardzo atrakcyjna droga edukacji w zakresie ekonomiki kultury. Mapowanie przemysłów kreatywnych samo generuje kreatywność myślenia, pogłębia wiedzę na temat kultury współczesnej i pozwala na głębsze zrozumienie generowanych przez nią procesów gospodarczych w danym regionie. $W$ gruncie rzeczy polega to na wywróceniu przemysłów kreatywnych „szwami na zewnątrz” - po to, by lepiej zrozumieć istotę ekonomiki kultury. 


\section{Bibliografia}

BOP Consulting, Mapowanie sektorów kreatywnych: narzędzia, tłum. J. Puchalska, British Council, Warszawa 2010.

Film $z$ widokiem na morze. 40 lat Festiwalu Filmowego Gdańsk - Gdynia, red.

A. Wróblewska, Stowarzyszenie Filmowców Polskich, Warszawa 2015.

Richard Florida, Narodziny klasy kreatywnej oraz jej wplyw na przeobrażenia w charakterze pracy, wypoczynku, społeczeństwa i życia codziennego, tłum.

M. Penkala, T. Krzyżanowski, Narodowe Centrum Kultury, Warszawa 2010.

Grażyna Gierszewska, Maria Romanowska, Analiza strategiczna przedsiębiorstwa, Państwowe Wydawnictwo Ekonomiczne, Warszawa 2009.

Peter Higgs, Stuart Cunningham, Creative Industries Mapping: Where have we come from and where are we going?, „Creative Industry Journal” 2008, vol. 1, nr 1.

Rafał Kasprzak, Przemysty kreatywne w Polsce. Uwarunkowania i perspektywy, Kamon Consulting, Warszawa 2013

Kultura i przemysty kultury szansa rozwojową dla Polski, red. J. Szomburg, Instytut Badań nad Gospodarką Rynkową, Centrum Animacji Kultury, Gdańsk 2002.

Od przemysłów kultury do kreatywnej gospodarki, red. A. Gwóźdź, Narodowe

Centrum Kultury, Warszawa 2010.

Monika Smoleń, Przemysty kultury. Wpływ na rozwój miast, Wydawnictwo UJ, Kraków 2003.

Krzysztof Stachowiak, Paulina Tomczak, Przestrzenny wymiar sektora kreatywnego,

Bogucki Wydawnictwo Naukowe, Poznań 2015.

Krzysztof Stachowiak, Problemy metodologiczne badania sektora kreatywnego, „Rozwój Regionalny i Polityka Regionalna” 2015, nr 30.

David Throsby, Ekonomia i kultura, tłum. O. Siara, Narodowe Centrum Kultury, Warszawa 2010.

David Throsby, The Economics of Cultural Policy, Cambridge UP, New York 2010.

Ruth Towse, Ekonomia kultury. Kompendium, tłum. Ł. Skrok, H. Dębowski, K.L. Pogorzelski, Narodowe Centrum Kultury, Warszawa 2011.

\section{Źródła internetowe}

Tomasz Kukołowicz, Dwa pomysty na przemysty kreatywne, referat wygłoszony podczas Regionalnego Kongresu Kultury w Łodzi, 27-29 X 2011 r.; www.kongres-kultury.pl. 
Anna Wróblewska, Duża dziura duży pomyst. W Gdyni buduja, http://www.portalfilmowy.pl/wydarzenia,5,19191,2,1,Duza-dziura-duzy-pomysl-W-Gdyni-buduja-foto.html.

\section{Mapping the Creative Sectors. In Search for Definitions and Method}

The author discusses a new method, rarely used in Poland so far - a method of mapping cultural industries and creative industries. The concept of mapping creative industries is founded on the Anglo-Saxon ground and goes beyond the usual plotting of the maps. This method enables countries, regions and cities to estimate the value of the creative sectors. It is based on determining a set of analytical methods for collecting and presenting information on the scale and the scope of the creative industries. In mapping, both quantitative and qualitative methods are used, as well as such sources of knowledge, as literature review, analysis of official government data, research on specific sectors, analysis of data from non-governmental sources, analysis of the industry informants and case studies. Mapping can be a valuable tool in lobbying the creative class, but its main purpose is to deepen the knowledge about this sector of the economy, which is still not sufficiently analyzed.

The author considers and analyses not only mapping as a way to describe the dynamic sectors of culture, but also the very definition of mapping the creative sector, outlining the opinion and comments of Krzysztof Stachowiak, a researcher of problems of concentration of cultural industries. What serves as a frame of the article, is the description of the film industry growing currently in Gdynia and the ways in which this mini-industry can be described using the principles of mapping creative industries.

Keywords: creative industry, cultural industry, mapping, film industry, audiovisual industry, film, Gdynia, film festival, film culture, film production, cinema, strategic analysis 